Rezime:

Na primeru izabranih sredstava lične NHB zaštite demonstrirana je primena metode procene kompatibilnosti, kao vrlo bitne taktičko-tehničke karakteristike za svako novouvedeno sredstvo naoružanja $i$ vojne opreme (NVO) u Vojsci Srbije. Utvrđeno je da zaštitno filtrirajuće odelo, zaštitni laki ogrtač i zaštitne rukavice ispunjavaju postavljene kriterijume kompatibilnosti. Opisana metoda provere kompatibilnosti može da se primenjuje i na druga sredstva NVO u fazama razvoja, proizvodnje $i$ eksploatacije.

Ključne reči: kompatibilnost, metoda, sredstva lične NHB zaštite.

\title{
METHOD OF TESTING COMPATIBILITY OF PERSONAL NBC PROTECTION DEVICES
}

\section{Summary:}

The selected personal NBC protection devices have served as an example for demonstrating the application of the compatibility evaluation method as a very important tactical - technical characteristic of each newly introduced item of weapon and military equipment in the Serbian army. It has been determined that a filtering protective suit, a light protective coat and protective gloves meet the required criteria of compatibility. The described method of testing compatibility can be also applied to other weapons and military equipment in stages of development, production and exploitation.

Key words: compatibility, method, personal NBC protection devices.

\section{Uvod}

Kompatibilnost NHB sredstava lične zaštite veoma je značajna, naročito sa stanovišta korisnika tih sredstava, zbog veće efikasnosti u korišćenju opreme, bolje fiziološke podobnosti i dužeg trajanja sredstava 
u uslovima eksploatacije. To znači da pri istovremenoj primeni ovih sredstava ona međusobno ne bi smela bitno da umanjuju osnovnu pojedinačnu funkciju, odnosno da njihova zajednička upotreba bitno ne utiče na smanjenje borbenih mogućnosti vojnika kao pojedinaca i jedinice u celini.

U literaturi ima malo konkretnih podataka o kompatibilnosti sredstava naoružanja i vojne opreme (NVO) vojnika, mada se ova karakteristika često navodi kao bitan uslov koji mora biti ispunjen.

Cilj ovog rada je: va NVO;

- da se ukaže na značaj kompatibilnosti u fazi konstrukcije sredsta-

- da se razradi, a u kasnijoj fazi i standardizuje metoda ispitivanja kompatibilnosti za trupnoeksploataciona ispitivanja u fazi verifikacije novorazvijenih sredstava NVO;

- da se u pogledu kompatibilnosti sredstava NVO postigne saglasnost na relaciji konstruktor sredstva - proizvođač - verifikator u fazi usvajanja sredstva u opremu VS - krajnji korisnik, tj. vojnik.

Na primeru filtrirajućeg zaštitnog odela (OFZ), zaštitnog lakog ogrtača (OZL) i zaštitnih čarapa (ČaZ) kompatibilnost je definisana teorijski i proverena praktično u terenskim uslovima ispitivanja, dok je za preostala sredstva lične NHB zaštite ona metodološki postavljena i definisana.

\section{Kompatibilnost NHB sredstava lične zaštite sa opremom vojnika Vojske Srbije}

Kompatibilnost posmatrana u sistemu NHB lične zaštite podrazumeva interakciju između sredstava lične NHB zaštite međusobno, ali i sa ostalom opremom vojnika. NHB sredstva lične zaštite u VS sačinjavaju zaštitna maska (MZ), zaštitni kombinezon ( $K Z)$, filtrirajuće zaštitno odelo (OFZ), zaštitni laki ogrtač (OZL), zaštitne čizme (ČZ), zaštitne čarape (ČaZ), zaštitne rukavice (RZ) i zaštitna kecelja (KeZ) (sl. 1).

Od navedenih sredstava svakom vojniku sleduje: MZ, OZL, RZ i ČaZ, dok su ostala sredstva namenjena samo određenim specijalnostima u okviru VS.

Oprema koju poseduje vojnik VS, i koja treba da bude kompatibilna sa NHB sredstvima lične zaštite, obuhvata: vojnu uniformu, šlem, zaštitni prsluk, borbeni ranac, cipele sa dužom sarom, lično naoružanje (puška, pištolj...), optička sredstva (dvogled, optički nišan, optička sredstva na oruđima...) i sredstva veze [1]. 


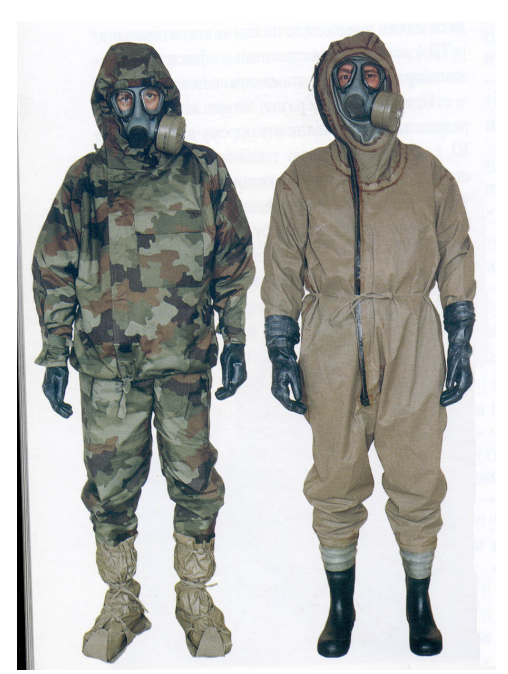

Slika 1 - Sredstva NHB lične zaštite razvijena u Vojnotehničkom institutu

U odnosu na projektovani model NVO [1], procenjuje se da bi vojnik pešadije pri izvršenju borbenih zadataka neprekidno nosio na sebi sledeća sredstva NVO: automatsku pušku (AP) sa potcevnim bacačem granata, balistički individualni računar, optoelektronski nišan, laserski obeleživač cilja, laserski merač daljine, uređaj za pozicioniranje u prostoru, uređaj veze, šlem, zaštitni balistički prsluk, zaštitnu masku, ratnu uniformu, individualni komplet za zagrevanje hrane, individualni sanitetski komplet, individualni komplet za osvetljavanje i signalizaciju, borbeni prsluk, potrebnu količinu individualnih resursa za autonomno izvršavanje borbenog zadatka (1 b/k municije za AP i potcevni bacač granata, ručna bomba, suvi dnevni obrok, 1 litar vode).

Navedena oprema koju bi nosio vojnik bila bi teška oko $27 \mathrm{~kg}$.

$U$ prognoziranim uslovima upotrebe $\mathrm{NHB}$ b/s na bojištu vojnik pešadije bi povremeno koristio sledeće komponente iz podsistema za preživljavanje na bojištu: OFZ, OZ, RZ, ČaZ, senzore za radiološku i hemijsku detekciju, kao i senzor za detekciju laserskog, elektromagnetnog i termalnog zračenja [1]. Time bi ukupna opterećenost bila povećana za oko $5 \mathrm{~kg}$.

\section{Kompatibilnost pojedinačnih NHB sredstava lične zaštite međusobno i sa opremom vojnika Zaštitna maska}

Zaštitna maska namenjena je za zaštitu organa za disanje, očiju i lica ljudi od RHB kontaminacije u vidu kapi, para, gasova, čvrstih i tečnih aerosola i čestica prašine, nastalih kao posledica upotrebe NHB oružja. Pored toga, 
MZ pruža zaštitu, uz odgovarajuća cedila, od kontaminacije nastale hemijskim udesima (3). U pogledu kompatibilnosti kod MZ M3 navedeno je da u zaštitnom položaju ona mora biti kompatibilna sa KZ, OZ, OFZ i šlemom [2]. Ovaj zahtev, međutim, treba proširiti prema svim ostalim sredstvima NVO koji su u nekoj vezi sa MZ. To znači da MZ treba da bude kompatibilna sa sledećim sredstvima NVO: OFZ, OZL, KZ, šlemom, zaštitnim balističkim prslukom, ličnim naoružanjem, optičkim sredstvima i sredstvima veze.

\section{Zaštitno filtrirajuće odelo}

Zaštitno filtrirajuće odelo namenjeno je za višekratnu zaštitu od dejstva para/gasova bojnih otrova (BOt) i jednokratnu zaštitu od dejstva kapi BOt-a, kao i za jednokratnu zaštitu od dejstva termalnog impulsa nuklearne eksplozije (TINE) i kapi goruće napalm smeše. Oblači se preko veša, a oblačenje i svlačenje mora biti jednostavno. U pogledu kompatibilnosti za OFZ se navodi da mora biti kompatibilno sa MZ, RZ, OZ, ČaZ, vojničkim šlemom M-97, borbenim balističkim prslukom i modularnim rancem [3]. Ovo odelo mora da omogući nesmetano izvršavanje svih borbenih radnji.

Naknadno izučavanje kompatibilnosti pokazalo je da OFZ mora da bude kompatibilno sa sledećim sredstvima NVO: MZ, RZ, ČZ, ČaZ, šlemom, borbenim rancem, zaštitnim prslukom, ratnom uniformom, cipelama sa dužom sarom i ličnim naoružanjem.

U odnosu na projektovani "Model opremanja vojnika pešadije“ [1], u situacijama kada se nosi, OFZ mora biti kompatibilno sa svim sredstvima NVO koja sleduju vojnika pešadije pri izvršenju borbenih zadataka.

\section{Laki zaštitni ogrtač}

Laki zaštitni ogrtač namenjen je za jednokratnu zaštitu vojnika, lične opreme i naoružanja od kapi BOt i višekratnu zaštitu od radioaktivnih i atmosferskih padavina (na KonZ-u) [4]. U pogledu kompatibilnosti, u TTZ-u [4] nisu postavljeni nikakvi zahtevi.

Očigledno je, međutim, da OZL mora biti kompatibilan sa sledećim sredstvima NVO: MZ, OFZ, šlemom, rancem borbenim, ratnom uniformom i ličnim naoružanjem.

U odnosu na projektovani „Model opremanja vojnika pešadije“, u situacijama kada je predviđeno da se nosi, OZL mora biti kompatibilan sa svim sredstvima NVO koja sleduju vojniku pešadije pri izvršenju borbenih zadataka.

\section{Zaštitne čizme}

Zaštitne čizme služe za zaštitu nogu od dejstva kapi i aerosola BOta i radioaktivnih čestica [5]. Treba da budu kompatibilne sa sledećim sredstvima NVO: OFZ, KZ i ratnom uniformom. 


\section{Zaštitne čarape}

Zaštitne čarape obezbeđuju zaštitu nogu i obuće od kontaminacije kapima, parama, i aerosolima BOt-a, tečnim i čvrstim radiološkim kontaminantima. One obezbeđuju zaštitu od plamena napalm smeše i TINE [6]. RZ, ČaZ, OZL i OFZ moraju međusobno biti kompatibilni, kao i sa ostalim delovima zaštitne opreme [6].

Zaštitne čarape treba da budu kompatibilne sa sledećim sredstvima NVO: cipelama sa dužom sarom, OFZ i ratnom uniformom.

U odnosu na projektovani „Model opremanja vojnika pešadije“ [1], u situacijama u kojima se nose, ČaZ moraju biti kompatibilne sa svim sredstvima NVO koja sleduju vojniku pešadije pri izvršenju borbenih zadataka.

\section{Zaštitni kombinezon}

Zaštitni kombinezon služi za zaštitu od kontaminacije BOt-om i radioaktivne kontaminacije [7]. Treba da bude kompatibilan sa: MZ, RZ, ČZ, ratnom uniformom, šlemom i ličnim naoružanjem.

U odnosu na projektovani „Model opremanja vojnika pešadije“ [1], u situacijama u kojima se nosi, KZ mora biti kompatibilan sa svim sredstvima NVO koja sleduju vojniku pešadije pri izvršenju borbenih zadataka.

\section{Zaštitne rukavice}

Zaštitne rukavice namenjene su za zaštitu ruku korisnika od para, aerosola i sitnih kapljica RHB kontaminanata i drugih toksičnih supstanci, kao i od dejstva TINE i zapaljivih sredstava tipa „napalm“ smeše [1]. Treba da budu kompatibilne sa ostalim sredstvima za ličnu NHB zaštitu tela, kao i sledećim sredstvima NVO: OFZ, KZ, ratnom uniformom, ličnim naoružanjem, sredstvima veze i preciznim instrumentima.

U odnosu na projektovani „Model opremanja vojnika pešadije“ [1], u situacijama u kojima se nose, RZ moraju biti kompatibilne sa svim sredstvima NVO koja sleduju vojniku pešadije pri izvršenju borbenih zadataka [1].

\section{Zaštitna kecelja}

Zaštitna kecelja treba da bude kompatibilna sa ratnom uniformom. 


\section{Metoda ispitivanja}

U toku dosadašnjeg istraživanja i razvoja NHB sredstava lične zaštite vršena su mnogobrojna opitno-eksploataciona ispitivanja. Pri tome se u izveštajima nigde ne pominje kompatibilnost kao pojam.

Razmatrajući ovu problematiku došlo se do zaključka da se kompatibilnost NHB sredstava lične zaštite sa opremom vojnika najbolje može obraditi metodološki putem ankete u saradnji sa vojnicima - ispitanicima i vizuelnog zapažanja, kako anketara, tako i ispitanika, i to u statičkim i dinamičkim uslovima.

Metodološki problemi su najvažniji i najteži. Tu spada, pre svega, odabiranje načina prikupljanja statističkih podataka, definisanje predmeta i jedinice posmatranja, odabiranje obeležja posmatranja, odabiranje metoda obrade prikupljenih podataka i mnoga druga pitanja u zavisnosti od cilja istraživanja.

Anketna metoda zasniva se na posmatranju unapred određenih jedinica radi prikupljanja neophodnih podataka za statističku procenu karakteristika statističke mase. Opšte karakteristike ankete su [8]:

a) predmet posmatranja je konačna masa slučajno odabranih jedinica posmatranja (uzorak);

b) informacije dobijene anketom imaju statistički karakter;

c) posmatranje se vrši neposredno i jednoobrazno;

d) posmatranje je delimično.

Uslovi za kvalitetno anketiranje ispitanika su: dobro osmišljena anketa; pitanja moraju biti jasno i stručno postavljena i neposredno usmerena na određeni problem; anketa se mora izvršiti odmah po završetku predviđenih radnji, dok su zapažanja ispitanika još sveža.

Pošto se anketa vrši za svako sredstvo NHB lične zaštite zasebno, to znači da specifičnosti sredstva određuju pitanja u anketi, kao i važnost i redosled pri zaključivanju o kompatibilnosti sa ostalom opremom vojnika VS.

Za bolju analizu ankete, za svako sredstvo za koje se proverava kompatibilnost sa ostalom opremom vojnika VS koristi se nekoliko novouvedenih pojmova poput nivoa relevantnosti kriterijuma koji se ocenjuje (5-10), ocene kompatibilnosti (1-5) i koeficijenta kompatibilnosti(Kk).

Anketa za proveru kompatibilnosti filtrirajućeg zaštitnog odela

$U$ tabeli 1 navedena je anketa za ispitivanje kompatibilnosti OFZ-a za slučajeve kada vojnik samostalno podešava opremu i/ili kada mu u tome pomaže drugi vojnik.

Pod kompatibilnošću u dinamičkim uslovima podrazumeva se izvršenje gađanja i kretanje na bojištu, a adekvatna anketa prikazana je u tabeli 2 . 
Anketa za ispitivanje kompatibilnosti OFZ u statičkim uslovima

\begin{tabular}{|c|c|c|c|c|c|c|}
\hline $\begin{array}{l}\text { Br. } \\
\text { parame- } \\
\text { tara, } \\
\mathrm{n}\end{array}$ & $\begin{array}{l}\text { Kriterijum koji se } \\
\text { ocenjuje }\end{array}$ & \begin{tabular}{|} 
A, \\
Nivo rele- \\
vantnosti \\
$(5-10)$
\end{tabular} & $\begin{array}{l}\text { B, } \\
\text { Ocena } \\
(1-5)\end{array}$ & $\begin{array}{l}\text { Broj } \\
\text { poena } \\
(A B)\end{array}$ & $\mathrm{Kk}$ & $\begin{array}{l}\text { Ocena } \\
\text { komp. } \\
\Sigma \mathrm{Kk} / \mathrm{n}\end{array}$ \\
\hline 1 & $\begin{array}{l}\text { Da li rubovi kapuljače OFZ dobro naležu } \\
\text { na ojačani prsten MZ }\end{array}$ & 9 & 4 & 36 & $36 / 45=0,8$ & \multirow{11}{*}{$\begin{array}{l}0,7 \\
\text { kompa- } \\
\text { tibilan }\end{array}$} \\
\hline 2 & Da li je spoj OFZ sa RZ dobar & 9 & 4 & 36 & $36 / 45=0,8$ & \\
\hline 3 & $\begin{array}{l}\text { Da li kapuljača OFZ utiče na polje vida } \\
\text { sa MZ u zaštitnom položaju }\end{array}$ & 8 & 4 & 32 & $32 / 40=0,8$ & \\
\hline 4 & $\begin{array}{l}\text { Da li zaštitni prsluk može da se obuče } \\
\text { preko OFZ }\end{array}$ & 8 & 4 & 32 & $32 / 40=0,8$ & \\
\hline 5 & $\begin{array}{l}\text { Da li je podbradna traka šlema dovoljno } \\
\text { duga da se može zakopčati preko } \\
\text { kapuljače OFZ-a }\end{array}$ & 7 & 3 & 21 & $21 / 35=0,6$ & \\
\hline 6 & $\begin{array}{l}\text { Da li veličina OFZ-a (V, S, M) obuhvata } \\
\text { svu vojničku populaciju, tj. da li je } \\
\text { OFZ udoban }\end{array}$ & 7 & 4 & 28 & $28 / 35=0,8$ & \\
\hline 7 & $\begin{array}{l}\text { Da li je korišćenje OFZ u letnjim uslovi- } \\
\text { ma, preko ratne uniforme, podnošljivo za } \\
\text { korisnika i u kojoj meri }\end{array}$ & 7 & 3 & 21 & $21 / 35=0,6$ & \\
\hline 8 & $\begin{array}{l}\text { Da li OFZ može da se obuče preko vojne } \\
\text { uniforme (letnja, zimska) i kakvi se } \\
\text { problemi tu javljaju }\end{array}$ & 7 & 4 & 28 & $28 / 35=0,8$ & \\
\hline 9 & $\begin{array}{l}\text { Da li se borbeni ranac može nositi preko } \\
\text { OFZ-a i kakvi se problemi (npr. dužina } \\
\text { ramenih traka, žuljanje...) javljaju }\end{array}$ & 6 & 3 & 18 & $18 / 30=0,6$ & \\
\hline 10 & $\begin{array}{l}\text { Koji problemi se javljaju pri nošenju } \\
\text { opasača sa ličnim naoružanjem } \\
\text { (pištolj, bomba, municija...) preko OFZ-a }\end{array}$ & 6 & 4 & 24 & $24 / 30=0,8$ & \\
\hline 11 & Da li ima problema pri nošenju ČaZ sa OFZ & 5 & 5 & 25 & $25 / 25=1$ & \\
\hline
\end{tabular}

Tabela 2

Ispitivanje kompatibilnosti OFZ-a putem ankete u dinamičkim uslovima

A) Izvršenje gađanja

\begin{tabular}{|c|l|c|c|c|c|c|}
\hline $\begin{array}{c}\text { Br. } \\
\text { parametara, } \\
\mathrm{n}\end{array}$ & \multicolumn{1}{|c|}{$\begin{array}{c}\text { Kriterijum koji se } \\
\text { ocenjuje }\end{array}$} & $\begin{array}{c}\mathrm{A}, \\
\text { Nivo } \\
\text { relevantnosti } \\
(5-10)\end{array}$ & $\begin{array}{c}\mathrm{B}, \\
\text { Ocena } \\
(1-5)\end{array}$ & $\begin{array}{c}\text { Broj } \\
\text { poena } \\
\text { (AB) }\end{array}$ & Kk & $\begin{array}{c}\text { Ocena } \\
\text { komp. } \\
\Sigma \mathrm{Kk} / \mathrm{n}\end{array}$ \\
\hline 1 & $\begin{array}{l}\text { Da li OFZ smeta korisniku pri } \\
\text { gađanju ličnim naoružanjem } \\
\text { (puška, puškomitraljez...) }\end{array}$ & 9 & 5 & 45 & $45 / 45=1$ & $\begin{array}{c}1 \\
\text { visoko- } \\
\text { kompa- } \\
\text { tibilan }\end{array}$ \\
\hline 2 & $\begin{array}{l}\text { Da li je korisniku koji nosi OFZ } \\
\text { remnik puške dovoljno dug pri } \\
\text { izvođenju gađanja tromblon- } \\
\text { skom minom }\end{array}$ & 7 & 5 & 35 & $35 / 35=1$ & \\
\hline
\end{tabular}


B) Kretanje na bojištu

\begin{tabular}{|c|c|c|c|c|c|c|}
\hline$\underset{\mathrm{Br} .}{\mathrm{Barametara}}$, & $\begin{array}{l}\text { Kriterijum koji se } \\
\text { ocenjuje }\end{array}$ & $\begin{array}{c}\text { A, } \\
\text { Nivo } \\
\text { relevantno- } \\
\text { sti } \\
(5-10)\end{array}$ & $\begin{array}{c}\text { B } \\
\text { Ocena } \\
(1-5)\end{array}$ & $\begin{array}{c}\text { Broj } \\
\text { poena } \\
\text { (AB) }\end{array}$ & Kk & $\begin{array}{l}\text { Ocena } \\
\text { komp. } \\
\Sigma \mathrm{Kk} / \mathrm{n}\end{array}$ \\
\hline 1 & $\begin{array}{l}\text { Da li OFZ smeta pri izvođenju marša u } \\
\text { odnosu na ostalu opremu vojnika (lično } \\
\text { naoružanje, ranac borbeni, MZ, itd.) }\end{array}$ & 9 & 5 & 45 & $45 / 45=1$ & \\
\hline 2 & $\begin{array}{l}\text { Da li OFZ smeta pri prevoženju u } \\
\text { borbenim i neborbenim } \mathrm{m} / \mathrm{v}\end{array}$ & 7 & 5 & 35 & $35 / 35=1$ & \multirow{5}{*}{$\begin{array}{c}1 \\
\text { visoko- } \\
\text { kompa } \\
\text { tibilan }\end{array}$} \\
\hline 3 & $\begin{array}{l}\text { Koliko i kako OFZ utiče na pretrčavanje } \\
\text { vojnika na bojištu }\end{array}$ & 7 & 5 & 35 & $35 / 35=1$ & \\
\hline 4 & Da li i kako OFZ smeta pri zaleganju & 7 & 5 & 35 & $35 / 35=1$ & \\
\hline 5 & $\begin{array}{l}\text { Kako OFZ smeta pri izradi zaklona za } \\
\text { ležeći stav }\end{array}$ & 7 & 5 & 35 & $35 / 35=1$ & \\
\hline 6 & $\begin{array}{l}\text { Kako spoljnja temperatura i atmosferske } \\
\text { prilike utiču na ispitanika koji nosi OFZ }\end{array}$ & 7 & 5 & 35 & $35 / 35=1$ & \\
\hline
\end{tabular}

Anketa za proveru kompatibilnosti zaštitnog lakog ogrtača

$\mathrm{U}$ tabeli 3 prikazana je anketa za ispitivanje kompatibilnosti OZL u statičkim uslovima, a odnosi se na slučajeve kada vojnik samostalno podešava svoju opremu i kada mu u tome pomaže drugi vojnik.

Tabela 3

Ispitivanje kompatibilnosti OZL u statičkim uslovima

\begin{tabular}{|c|c|c|c|c|c|c|}
\hline $\begin{array}{c}\text { Br. para- } \\
\text { metara, } \\
\mathrm{n}\end{array}$ & $\begin{array}{l}\text { Kriterijum koji se } \\
\text { ocenjuje }\end{array}$ & $\begin{array}{c}\text { A, } \\
\text { Nivo } \\
\text { relevantno- } \\
\text { sti } \\
(5-10) \\
\end{array}$ & $\begin{array}{c}\text { B, } \\
\text { Ocena } \\
(1-5)\end{array}$ & $\begin{array}{c}\text { Broj } \\
\text { poena } \\
(\mathrm{AB})\end{array}$ & Kk & $\begin{array}{l}\text { Ocena } \\
\text { komp. } \\
\Sigma \mathrm{Kk} / \mathrm{n}\end{array}$ \\
\hline 1 & $\begin{array}{l}\text { Da li kapuljača OZL smeta pri disanju, } \\
\text { kada je MZ u zaštitnom položaju }\end{array}$ & 9 & 4 & 36 & $36 / 45=0,8$ & \\
\hline 2 & $\begin{array}{l}\text { Da li OZL smeta pri držanju ličnog } \\
\text { naoružanja o desno rame }\end{array}$ & 8 & 3 & 24 & $24 / 40=0,6$ & \multirow{6}{*}{$\begin{array}{c}0,54 \\
\text { kompa- } \\
\text { tibilan }\end{array}$} \\
\hline 3 & $\begin{array}{l}\text { Da li kapuljača OZL utiče na polje } \\
\text { vida kada se koristi zajedno sa } \\
\text { OFZ i MZ u zaštitnom položaju }\end{array}$ & 8 & 2 & 16 & $16 / 40=0,4$ & \\
\hline 4 & $\begin{array}{l}\text { Da li kapuljača OZL smanjuje polje } \\
\text { vida }\end{array}$ & 8 & 2 & 16 & $16 / 40=0,4$ & \\
\hline 5 & $\begin{array}{l}\text { Da li se OZL može dobro namestiti } \\
\text { kada je šlem na glavi }\end{array}$ & 7 & 3 & 21 & $21 / 35=0,6$ & \\
\hline 6 & $\begin{array}{l}\text { Da li ima problema pri nošenju OZL } \\
\text { u zimskim uslovima, kada se nosi } \\
\text { vetrovka }\end{array}$ & 7 & 3 & 21 & $21 / 35=0,6$ & \\
\hline 7 & $\begin{array}{l}\text { Da li se može nositi borbeni ranac } \\
\text { ispod OZL }\end{array}$ & 6 & 2 & 12 & $12 / 30=0,4$ & \\
\hline
\end{tabular}


U tabeli 4 prikazana je metoda ispitivanja kompatibilnosti OZL u dinamičkim uslovima.

Tabela 4

Ispitivanje kompatibilnosti OZL u dinamičkim uslovima

A) Izvršenje gađanja

\begin{tabular}{|c|l|c|c|c|c|c|}
\hline $\begin{array}{c}\text { Br. } \\
\text { parametara, } \\
n\end{array}$ & \multicolumn{1}{|c|}{$\begin{array}{c}\text { Kriterijum koji se } \\
\text { ocenjuje }\end{array}$} & $\begin{array}{c}\text { A, } \\
\text { Nivo } \\
\text { relevantnosti } \\
(5-10)\end{array}$ & $\begin{array}{c}\text { B, } \\
\text { Ocena } \\
(1-5)\end{array}$ & $\begin{array}{c}\text { Broj } \\
\text { poena } \\
(\mathrm{AB})\end{array}$ & Kk & $\begin{array}{c}\text { Ocena } \\
\text { komp. } \\
\Sigma \mathrm{Kk} / \mathrm{n}\end{array}$ \\
\hline 1 & $\begin{array}{l}\text { Da li kapuljača OZL } \\
\text { navučena preko šlema smeta } \\
\text { pri nišanjenju }\end{array}$ & 10 & 3 & 30 & $30 / 50=0,6$ & \\
\cline { 1 - 5 } & $\begin{array}{l}\text { Da li OZL smeta pri punjenju } \\
\text { i pražnjenju ličnog } \\
\text { naoružanja u ležećem, } \\
\text { klečećem i stojećem stavu }\end{array}$ & 9 & 3 & 27 & $27 / 40=0,7$ & $\begin{array}{c}0,56 \\
\text { kompa- } \\
\text { tibilan }\end{array}$ \\
\cline { 1 - 4 } & $\begin{array}{l}\text { Da li i kako OZL smeta pri } \\
\text { upotrebi ručnog raketnog } \\
\text { bacača }\end{array}$ & 8 & 2 & 16 & $16 / 40=0,4$ & \\
\hline
\end{tabular}

B) Kretanje na bojištu

\begin{tabular}{|c|c|c|c|c|c|c|}
\hline $\begin{array}{c}\mathrm{Br} . \\
\text { parametar } \\
\mathrm{a}, \mathrm{n}\end{array}$ & $\begin{array}{l}\text { Kriterijum koji se } \\
\text { ocenjuje }\end{array}$ & $\begin{array}{c}\text { A } \\
\text { Nivo } \\
\text { relevantnosti } \\
(5-10)\end{array}$ & $\begin{array}{c}B \\
\text { Ocena } \\
(1-5)\end{array}$ & $\begin{array}{l}\text { Broj } \\
\text { poena } \\
\text { (AB) }\end{array}$ & Kk & $\begin{array}{l}\text { Ocena } \\
\text { komp. } \\
\Sigma \mathrm{Kk} / \mathrm{n}\end{array}$ \\
\hline 1 & $\begin{array}{l}\text { Da li i kako OZL smeta pri izvođenju } \\
\text { marša }\end{array}$ & 9 & 3 & 27 & $27 / 45=06$ & \multirow{5}{*}{$\begin{array}{c}0,52 \\
\text { kompa- } \\
\text { tibilan }\end{array}$} \\
\hline 2 & $\begin{array}{l}\text { Da li i kako OZL smeta pri ulaženju } \\
\text { i izlaženju iz borbenih i neborbenih } \\
\mathrm{m} / \mathrm{v} \text { (brzina ukrcavanja i iskrcavanja) }\end{array}$ & 8 & 3 & 24 & $24 / 40=0,6$ & \\
\hline 3 & $\begin{array}{l}\text { Da li OZL smeta pri pretrčavanju } \\
\text { na bojištu (bez rastinja, sa visokim } \\
\text { rastinjem, sa niskim rastinjem, } \\
\text { sa trnjem...) }\end{array}$ & 8 & 2 & 16 & $16 / 40=0,4$ & \\
\hline 4 & $\begin{array}{l}\text { Da li i kako OZL smeta pri zaleganju } \\
\text { i ustajanju u toku izvođenja borbenih } \\
\text { radnji na bojištu }\end{array}$ & 8 & 2 & 16 & $16 / 40=0,4$ & \\
\hline 5 & $\begin{array}{l}\text { Kako i koliko OZL smeta pri izradi } \\
\text { zaklona za ležeći stav }\end{array}$ & 7 & 3 & 21 & $21 / 35=0,6$ & \\
\hline
\end{tabular}

Anketa za ispitivanje kompatibilnosti zaštitnog kombinezona

Zaštitni kombinezon je sredstvo za ličnu NHB zaštitu, a koriste ga specijalne jedinice i pojedinci (jedinice ABHO i NHB izviđači i dekontaminatori u ostalim jedinicama).

$\mathrm{U}$ tabeli 5 prikazano je ispitivanje kompatibilnosti $\mathrm{KZ}$ u statičkim uslovima, a u tabeli 8 u dinamičkim uslovima. 
Kompatibilnost u statičkim uslovima odnosi se na slučaj kada vojnik samostalno podešava opremu i kada mu u tome pomaže drugi vojnik.

\section{Tabela 5}

Anketa za ispitivanje kompatibilnosti $\mathrm{KZ}$ u statičkim uslovima

\begin{tabular}{|c|c|c|c|c|c|c|}
\hline $\begin{array}{c}\mathrm{Br} . \\
\text { parametara, } \\
\mathrm{n}\end{array}$ & $\begin{array}{l}\text { Kriterijum koji se } \\
\text { ocenjuje }\end{array}$ & $\begin{array}{c}\text { A, } \\
\text { Nivo } \\
\text { relevantnosti } \\
(5-10)\end{array}$ & $\begin{array}{l}\text { B, } \\
\text { Ocena } \\
(1-5)\end{array}$ & $\begin{array}{l}\text { Broj } \\
\text { poena } \\
\text { (AB) }\end{array}$ & $\mathrm{Kk}$ & $\begin{array}{l}\text { Ocena } \\
\text { komp. } \\
\Sigma \mathrm{Kk} / \mathrm{n}\end{array}$ \\
\hline 1 & $\begin{array}{l}\text { Da li kapuljača KZ dobro } \\
\text { naleže na ojačani deo MZ }\end{array}$ & 9 & & & & \\
\hline 2 & $\begin{array}{l}\text { Da li je dobar spoj } R Z \text { sa } \\
\text { rukavima } K Z\end{array}$ & 8 & & & & \\
\hline 3 & $\begin{array}{l}\text { Da li je dobar spoj ČZ sa } \\
\text { nogavicama KZ }\end{array}$ & 7 & & & & \\
\hline 4 & $\begin{array}{l}\text { Da li je dužina podbradne } \\
\text { trake šlema dovoljna pri } \\
\text { nošenju sa KZ }\end{array}$ & 6 & & & & \\
\hline
\end{tabular}

Tabela 6

Anketa za ispitivanje kompatibilnosti $\mathrm{KZ}$ u dinamičkim uslovima A) $U$ radu pri izviđanju i dekontaminaciji

\begin{tabular}{|c|c|c|c|c|c|c|}
\hline $\begin{array}{c}\text { Br. parametara, } \\
n\end{array}$ & $\begin{array}{l}\text { Kriterijum koji se } \\
\text { ocenjuje }\end{array}$ & $\begin{array}{c}\mathrm{A}, \\
\text { Nivo relevantnosti } \\
(5-10)\end{array}$ & $\begin{array}{c}\mathrm{B} \\
\text { Ocena } \\
(1-5)\end{array}$ & $\begin{array}{c}\text { Broj } \\
\text { poena } \\
(\mathrm{AB})\end{array}$ & $\mathrm{Kk}$ & $\begin{array}{l}\text { Ocena } \\
\text { komp. } \\
\Sigma \mathrm{Kk} / \mathrm{n}\end{array}$ \\
\hline 1 & $\begin{array}{l}\text { Kako KZ smeta pri } \\
\text { izvršenju radnji izviđača } \\
\text { ABHO }\end{array}$ & 9 & & & & \\
\hline 2 & $\begin{array}{l}\text { Koliko i da li KZ smeta } \\
\text { pri izvršenju radnji na } \\
\text { dekontaminacionoj } \\
\text { stanici (u toku pripreme } \\
\text { i izvršenja } \\
\text { dekontaminacije) }\end{array}$ & 8 & & & & \\
\hline
\end{tabular}

B) Kretanje na bojištu

\begin{tabular}{|c|c|c|c|c|c|c|}
\hline $\begin{array}{c}\mathrm{Br} . \\
\text { parametara, } \\
\mathrm{n}\end{array}$ & $\begin{array}{l}\text { Kriterijum koji se } \\
\text { ocenjuje }\end{array}$ & $\begin{array}{c}\text { A, } \\
\text { Nivo } \\
\text { relevantnosti } \\
(5-10)\end{array}$ & $\begin{array}{c}\text { B, } \\
\text { Ocena } \\
(1-5)\end{array}$ & $\begin{array}{l}\text { Broj } \\
\text { poena } \\
(A B)\end{array}$ & $\mathrm{Kk}$ & $\begin{array}{l}\text { Ocena } \\
\text { komp. } \\
\Sigma \mathrm{Kk} / \mathrm{n}\end{array}$ \\
\hline 1 & $\begin{array}{l}\text { Da li i kako KZ smeta pri } \\
\text { pretrčavanju (kretanje ABHO } \\
\text { izviđača, odbrana mesta za } \\
\text { дekontaminaciju...) }\end{array}$ & 9 & & & & \\
\hline 2 & $\begin{array}{l}\text { Da li KZ smeta pri dejstvu } \\
\text { iz ličnog naoružanja }\end{array}$ & 9 & & & & \\
\hline 3 & $\begin{array}{l}\text { Da li i kako KZ smeta pri } \\
\text { zaleganju }\end{array}$ & 7 & & & & \\
\hline
\end{tabular}


Anketa za ispitivanje kompatibilnosti zaštitnih čizama

$U$ tabeli 7 prikazano je ispitivanje kompatibilnosti ČZ u statičkim uslovima, a u tabeli 8 u dinamičkim uslovima.

Tabela 7

Anketa za ispitivanje kompatibilnosti ČZ u statičkim uslovima

\begin{tabular}{|c|c|c|c|c|c|c|}
\hline $\begin{array}{c}\mathrm{Br} . \\
\text { parametara, } \\
\mathrm{n}\end{array}$ & $\begin{array}{l}\text { Kriterijum koji se } \\
\text { ocenjuje }\end{array}$ & $\begin{array}{c}\mathrm{A}, \\
\text { Nivo } \\
\text { relevantnosti } \\
(5-10)\end{array}$ & $\begin{array}{c}B, \\
\text { Ocena } \\
(1-5)\end{array}$ & $\begin{array}{c}\text { Broj } \\
\text { poena } \\
(\mathrm{AB})\end{array}$ & $\mathrm{Kk}$ & $\begin{array}{l}\text { Ocena } \\
\text { komp. } \\
\Sigma \mathrm{Kk} / \mathrm{n}\end{array}$ \\
\hline 1 & $\begin{array}{l}\text { Da li je spoj ČZ i nogavica OFZ } \\
\text { hermetičan }\end{array}$ & 9 & & & & \\
\hline 2 & $\begin{array}{l}\text { Da li je spoj ČZ i nogavica KZ } \\
\text { hermetičan }\end{array}$ & 9 & & & & \\
\hline 3 & $\begin{array}{l}\text { Da li su ČZ udobne (da li žuljaju } \\
\text { po obodu sare) }\end{array}$ & 8 & & & & \\
\hline 4 & $\begin{array}{l}\text { Da li se i koliko znoje noge } \\
\text { ispitanika u ČZ }\end{array}$ & 6 & & & & \\
\hline
\end{tabular}

Tabela 8

Anketa za ispitivanje kompatibilnosti ČZ u dinamičkim uslovima

\begin{tabular}{|c|c|c|c|c|c|c|}
\hline $\begin{array}{l}\mathrm{Br} . \\
\text { parametara, } \\
\mathrm{n}\end{array}$ & $\begin{array}{l}\text { Kriterijum koji se } \\
\text { ocenjuje }\end{array}$ & $\begin{array}{c}\text { A, } \\
\text { Nivo } \\
\text { relevantnosti } \\
(5-10)\end{array}$ & $\begin{array}{l}\mathrm{B} \\
\text { Ocena } \\
(1-5)\end{array}$ & $\begin{array}{l}\text { Broj } \\
\text { poena } \\
(\mathrm{AB})\end{array}$ & $\mathrm{Kk}$ & $\begin{array}{l}\text { Ocena } \\
\text { komp. } \\
\Sigma \mathrm{Kk} / \mathrm{n}\end{array}$ \\
\hline 1 & $\begin{array}{l}\text { Da li ČZ žuljaju po obodu sare pri } \\
\text { dužem hodanju (izviđanje i } \\
\text { dekontaminacija) }\end{array}$ & 9 & & & & \\
\hline 2 & $\begin{array}{l}\text { Da li ČZ žuljaju na spoju sa KZ, } \\
\text { pri izviđanju i dekontaminaciji }\end{array}$ & 8 & & & & \\
\hline 3 & $\begin{array}{l}\text { Da li ČZ žuljaju na spoju sa OFZ, } \\
\text { pri izviđanju i dekontaminaciji }\end{array}$ & 8 & & & & \\
\hline 4 & $\begin{array}{l}\text { Da li pri dužem nošenju, usled } \\
\text { znojenja nogu, dolazi do klizanja } \\
\text { unutar čizme }\end{array}$ & 6 & & & & \\
\hline
\end{tabular}

Anketa za ispitivanje kompatibilnosti zaštitnih rukavica

$U$ tabeli 9 data je METODA ispitivanja kompatibilnosti RZ u statičkim uslovima, a u tabeli 10 u dinamičkim uslovima.

Tabela 9

Ispitivanje kompatibilnosti RZ u statičkim uslovima

\begin{tabular}{|c|c|c|c|c|c|c|}
\hline $\begin{array}{c}\mathrm{Br} . \\
\text { parametara, } \\
\mathrm{n}\end{array}$ & $\begin{array}{l}\text { Kriterijum koji se } \\
\text { ocenjuje }\end{array}$ & $\begin{array}{c}\text { A, Nivo } \\
\text { relevantnosti } \\
(5-10)\end{array}$ & $\begin{array}{c}\mathrm{B}, \\
\text { Ocena } \\
(1-5)\end{array}$ & $\begin{array}{c}\text { Broj } \\
\text { poena } \\
\text { (AB) }\end{array}$ & $\mathrm{Kk}$ & $\begin{array}{l}\text { Ocena } \\
\text { komp. } \\
\Sigma \mathrm{Kk} / \mathrm{n}\end{array}$ \\
\hline 1 & $\begin{array}{l}\text { Da li je hermetičan spoj RZ sa } \\
\text { KZ }\end{array}$ & 9 & & & & \\
\hline 2 & $\begin{array}{l}\text { Da li je hermetičan spoj RZ i } \\
\text { OFZ }\end{array}$ & 9 & & & & \\
\hline 3 & $\begin{array}{l}\text { Da li RZ smetaju pri rukovanju } \\
\text { ličnim naoružanjem }\end{array}$ & 7 & & & & \\
\hline
\end{tabular}


Ispitivanje kompatibilnosti $R Z$ u dinamičkim uslovima

A) Pri izvođenju gađanja

\begin{tabular}{|c|c|c|c|c|c|c|}
\hline $\begin{array}{l}\mathrm{Br} . \\
\text { parametara, } \\
\mathrm{n}\end{array}$ & $\begin{array}{l}\text { Kriterijum koji se } \\
\text { ocenjuje }\end{array}$ & $\begin{array}{c}\mathrm{A}, \\
\text { Nivo } \\
\text { relevantnosti } \\
(5-10)\end{array}$ & $\begin{array}{c}\text { B, } \\
\text { Ocena } \\
(1-5)\end{array}$ & $\begin{array}{c}\text { Broj } \\
\text { poena } \\
(A B)\end{array}$ & $\mathrm{Kk}$ & $\begin{array}{l}\text { Ocena } \\
\text { komp. } \\
\Sigma \mathrm{Kk} / \mathrm{n}\end{array}$ \\
\hline 1 & $\begin{array}{l}\text { Da li i kako RZ smetaju pri } \\
\text { punjenju i pražnjenju ličnog } \\
\text { naoružanja (okvira AP, PM, } \\
\text { punjenja pištolja, itd.) }\end{array}$ & 9 & & & & \\
\hline 2 & $\begin{array}{l}\text { Da li i kako RZ smetaju pri } \\
\text { izvršenju okidanja u toku gađanja }\end{array}$ & 9 & & & & \\
\hline 3 & $\begin{array}{l}\text { Da li i kako RZ smetaju pri } \\
\text { bacanju bombe }\end{array}$ & 8 & & & & \\
\hline
\end{tabular}

B) $\mathrm{Na}$ bojištu

\begin{tabular}{|c|c|c|c|c|c|c|}
\hline$\underset{\mathrm{n}}{\mathrm{Br} .}$ & $\begin{array}{l}\text { Kriterijum koji se } \\
\text { ocenjuje }\end{array}$ & $\begin{array}{c}\text { A, } \\
\text { Nivo } \\
\text { relevantnosti } \\
(5-10)\end{array}$ & $\begin{array}{c}\mathrm{B} \\
\text { Ocena } \\
(1-5)\end{array}$ & $\begin{array}{l}\text { Broj } \\
\text { poena } \\
(\mathrm{AB})\end{array}$ & Kk & $\begin{array}{l}\text { Ocena } \\
\text { komp. } \\
\Sigma \mathrm{Kk} / \mathrm{n}\end{array}$ \\
\hline 1 & $\begin{array}{l}\text { Da li RZ smetaju pri rukovanju } \\
\text { uređajima i instrumentima } \\
\text { (sredstvima veze, radiološki } \\
\text { detektor, hemijski detektor, itd.) }\end{array}$ & 9 & & & & \\
\hline 2 & $\begin{array}{l}\text { Da li RZ smetaju pri podešavanju } \\
\text { nišanskih sprava (npr. RB) }\end{array}$ & 8 & & & & \\
\hline 3 & $\begin{array}{l}\text { Da li RZ smetaju pri upotrebi } \\
\text { ručnih raketnih bacača }\end{array}$ & 8 & & & & \\
\hline 4 & $\begin{array}{l}\text { Da li RZ smetaju pri pružanju } \\
\text { prve pomoći ranjenom ili } \\
\text { povređenom licu }\end{array}$ & 7 & & & & \\
\hline
\end{tabular}

Anketa za ispitivanje kompatibilnosti zaštitnih čarapa

$\mathrm{U}$ tabeli 11 prikazana je anketa za ispitivanje kompatibilnosti ČaZ.

Ispitivanje kompatibilnosti ČaZ pomoću ankete

Tabela 11

\begin{tabular}{|c|l|c|c|c|c|c|}
\hline $\begin{array}{c}\text { Br. } \\
\text { parametara, } \\
\mathrm{n}\end{array}$ & \multicolumn{1}{|c|}{$\begin{array}{c}\text { Kriterijum koji se } \\
\text { ocenjuje }\end{array}$} & $\begin{array}{c}\mathrm{A}, \\
\text { Nivo } \\
\text { relevantnosti } \\
(5-10)\end{array}$ & $\begin{array}{c}\mathrm{B}, \\
\text { Ocena } \\
(1-5)\end{array}$ & $\begin{array}{c}\text { Broj } \\
\text { poena } \\
\text { (AB) }\end{array}$ & Kk & $\begin{array}{c}\text { Ocena } \\
\text { komp. } \\
\Sigma \mathrm{Kk} / \mathrm{n}\end{array}$ \\
\hline 1 & $\begin{array}{l}\text { Da li se može nesmetano } \\
\text { hodati kada se ČaZ obuku } \\
\text { preko cipela sa dužom sarom } \\
\text { (asfaltni put, makadam, } \\
\text { kamenjar, put obrastao niskim } \\
\text { trnovitim rastinjem) }\end{array}$ & 9 & 46 & $36 / 45=0,8$ & 0,9 \\
VISOKO \\
KOMPA- \\
TIBILNO
\end{tabular}




\section{Anketa za ispitivanje kompatibilnosti zaštitne kecelje}

U tabeli 12 prikazana je anketa za ispitivanje komapatibilnosti KZ.

Ispitivanje kompatibilnosti zaštitne kecelje pomoću ankete

Tabela 12

Ispitivanje kompatibilnosti zaštitne kecelje pomoću ankete

\begin{tabular}{|c|l|c|c|c|c|c|}
\hline $\begin{array}{c}\text { Br. } \\
\text { parametara, } \\
\mathrm{n}\end{array}$ & \multicolumn{1}{|c|}{$\begin{array}{c}\text { Kriterijum koji se } \\
\text { ocenjuje }\end{array}$} & $\begin{array}{c}\mathrm{A}, \\
\text { Nivo } \\
\text { relevantnosti } \\
(5-10)\end{array}$ & $\begin{array}{c}\mathrm{B}, \\
\text { Ocena } \\
(1-5)\end{array}$ & $\begin{array}{c}\text { Broj } \\
\text { poena } \\
\text { (AB) }\end{array}$ & Kk & $\begin{array}{c}\text { Ocena } \\
\text { komp. } \\
\Sigma \mathrm{Kk} / \mathrm{n}\end{array}$ \\
\hline 1 & $\begin{array}{l}\text { Da li je dovoljno duga okovratna } \\
\text { traka KZ kada se nosi preko } \\
\text { zimske uniforme (vetrovka) }\end{array}$ & 9 & & & \\
\cline { 1 - 5 } & $\begin{array}{l}\text { Da li je dovoljno duga traka koja } \\
\text { ide oko struka kada se KZ nosi } \\
\text { preko zimske uniforme (vetrovke) }\end{array}$ & 8 & & & \\
\hline
\end{tabular}

\section{Vizuelni pregled}

Radi dopune ocene o kompatibilnosti, dobijene putem ankete, neophodno je da anketar zapiše svoja vizuelna zapažanja u toku ispitivanja, a bilo bi poželjno da to isto urade $\mathrm{i}$ ispitanici. Vrlo je značajno da ispitivač pravovremeno reaguje kada uoči da ispitanik nepravilno nosi sredstava NHB zaštite.

\section{Analiza}

Posle praktičnih ispitivanja, anketiranja i beleženja zapažanja u toku izvođenja predviđenih radnji treba izvršiti temeljnu analizu na osnovu koje se daje ocena ispunjenja kompatibilnih karakteristika ispitivanog sredstva.

Sa stanovišta kriterijuma koji se ocenjuje bira se ona karakteristika sredstva koja je, u odnosu prema nekom drugom sredstvu, značajna sa stanovišta kompatibilnosti. Ta karakteristika se vrednuje preko parametra - nivoa relevantnosti, koji se izražava ocenom od 5 (veoma mali uticaj na kompatibilnost) do 10 (izvanredan uticaj na kompatibilnost). Zatim se ocenjuje zadovoljenje postavljenog kriterijuma ocenama od 1 (nije kompatibilan) do 5 (visoko kompatibilan). Između nivoa relevantnosti i ocene kompatibilnosti postavljena je korelacija data u tabeli 13. 
Zavisnost između nivoa relevantnosti kompatibilnosti i visine ocene

Tabela 13

\begin{tabular}{|c|c|}
\hline $\begin{array}{c}\text { Nivo relevantnosti } \\
(5-10)\end{array}$ & $\begin{array}{c}\text { Minimalna dozvoljena ocena } \\
(1-5)\end{array}$ \\
\hline 10 & 3 \\
\hline 9 & 2 \\
\hline 8 & 2 \\
\hline 7 & 1 \\
\hline 6 & 1 \\
\hline 5 & 1 \\
\hline
\end{tabular}

Ukoliko je data ocena ispod minimalno dozvoljene, sredstvo ne zadovoljava uslov kompatibilnosti, bez obzira na ostale kriterijume. Ukoliko je zadovoljen ovaj nužan uslov, ide se na proračun koeficijenta kompatibilnosti Kk. Njegova vrednost mora biti $\geq 0,5$. Ukoliko taj uslov nije ispunjen sredstvo nije kompatibilno.

\section{Zaključak}

$U$ radu je prikazana originalna metoda ispitivanja kompatibilnosti sredstava NHB lične zaštite međusobno i sa ostalom opremom vojnika VS. Pri tome je utvrđeno:

1. Ocenjena je međusobna kompatibilnost NHB sredstava lične zaštite: zaštitne maske, filtrirajućeg zaštitnog odela, lakog zaštitnog ogrtača, zaštitnih čarapa, zaštitnih čizama, zaštitnih rukavica, zaštitnog kombinezona i zaštitne kecelje, ali isto tako i njihova kompatibilnost sa ostalim sredstvima NVO koja sleduju vojniku VS.

2. Metoda ispitivanja kompatibilnosti zasniva se na kvalitativnoj oceni datoj kroz anketiranje korisnika NHB sredstava lične zaštite i kvantitativnoj oceni vrednovanjem kompatibilnosti preko faktora kompatibilnosti Kk, koji predstavlja odnos između eksploataciono određene kompatibilnosti i maksimalno teorijski moguće. Taj odnos, tj. faktor Kk, mora da bude $\geq 0,5$, kako bi sredstvo bilo proglašeno za kompatibilno.

3. Za sva sredstva NHB lične zaštite teorijski je razrađena metoda ispitivanja kompatibilnosti. Za filtrirajuće zaštitno odelo $M 2$, laki zaštitni ogrtač i zaštitne čarape M2 postavljena metoda ispitivanja kompatibilnosti verifikovana je kroz eksploataciona ispitivanja.

4. Dobijeni rezultati ispitivanja kompatibilnosti filtrirajućeg zaštitnog odela M2, lakog zaštitnog ogrtača i zaštitnih čarapa M2 ukazuju na to da je izabrana metoda ispitivanja u potpunosti zadovoljila.

Ovaj rad predstavlja nastavak razrade ideje da se na primeru sredstava lične NHB zaštite metodološki ukaže na mogući način prilaženja ovoj tematici. Da bi se došlo do faze prihvatanja metode za ocenu kom- 
patibilnosti bilo kojeg sredstva NVO u VS, očigledno je da se ova aktivnost mora nastaviti i kroz praktičan rad dalje proveravati i dograđivati, a u zavisnosti od specifičnosti svakog pojedinačnog sredstva NVO.

\section{Literatura}

[1] Projektni zadatak: Model opremanja vojnika pešadije u funkciji optimizacije borbene efikasnosti, autonomnosti u izvršavanju borbenih zadataka i mogućnosti preživljavanja na bojištu, GŠ VJ, Sektor za KoV, Uprava pešadije, 2001.

[2] Maska zaštitna M-3, program realizacije, VTI br. 6535506.

[3] Odelo filtrirajuće zaštitno, program realizacije, VTI br. 6543504.

[4] Ogrtač zaštitni laki, program realizacije, VTI br. 6543505.

[5] Čizme zaštitne M-5, PKP, VTI br. 6257.

[6] Čarape zaštitne M2, program realizacije, VTI br. 6543505.

[7] Kombinezon zaštitni M-5. PKP, VTI 0031/85.

[8] Veljković, V., Poslovna statistika, Naučna knjiga, Beograd, 1992. 